\title{
A STANDARDIZATION OF THE ELECTRICAL METROLOGY LABORATORY COMPETENCE FOR DC VOLTAGE UNIT
}

\author{
Hadi Sardjono
}

\begin{abstract}
Abstrak
Sebagai Laboratorium Metrologi Nasional, Puslit KIM-LIPI berkewajiban untuk memelihara salah satu besaran kelistrikan yaitu standar tegangan dc 10V. Proses pemeliharaan dilakukan berdasarkan ketertelusuran dan uji banding antar laboratorium metrologi nasional negara lain. Pada proses ketertelusuran dipenuhi dengan mengkalibrasi sel standar 10V ke laboratorium Nasional Australia (NMIA). Sedangkan proses uji banding dilakukan bekerjasama dengan laboratorium nasional Singapura (SPRING). Dari hasil uji banding diperoleh nilai validasi kompetensi berdasarkan nilai En yaitu sebesar -0.25 .
\end{abstract}

Kata Kunci : Standarisasi, kompetensi, metrologi kelistrikan, tegangan dc.

\section{INTRODUCTION}

It is well known, Puslit KIM-LIPI is one of the LIPI Research centres that is responsible to maintaince almost all of the metrology unit especially on the electrical unit for dc voltage standard. The primary standard of the dc voltage standard is developed based on a group of the $10 \mathrm{~V}$ standard cells. Actually, the standard value of the $10 \mathrm{~V}$ is derived from the average of 4 standard cells in a group that is developed by a dessimination process referring to the standard value belong to the National Measurement Institute of Australia (NMIA) through a transfer standard.

Principally, It was defined in the ISO that the measured of the laboratory competence are basically performed by traceability chart and measurement recognization. In other words we can says that although the traceability is well done, to get their recognize competence, still it need to be complete by involving the laboratory to attend an ILC programm. The ILC program itself can be propose in form of an APMP (Asia Pasific Metrology Program) or bilateral (between two countries).

As a nasional metrology insttutes, one of the main important missions is to carry out the consistance of improvement in the competence quality. According to the declaration of the Mutual Recognition Arrangement (MRA), the competence quality of the laboratory can be observed if the laboratory has been participated in the ILC program and passed from a technical assessment process under coordinated by a legal Accreditation Body.

Puslit KIM-LIPI, Indonesia and SPRING, Singapore has made an arrangement to conduct a bilateral key comparison on dc voltage. As the comparison coordination, Puslit KIM-LIPI is proposed as the pilot laboratory. The comparison voltage is done at $10 \mathrm{~V}$. It was shown based on these ILC program, Puslit KIM-LIPI can observed their En up to -0.25 . The number of En is shown tendenciously to declare that the competence is conformed.

\subsection{Basic Theory}

Calibration laboratories are generally working to different levels of accuracy. Consequently, their performance is not judged by comparing their results with those of the other laboratories. Instead, their results are compared only to the Reference Laboratory's result and their ability to achieve the accuracy for which they are accredited is evaluated by calculating the En ratio $^{3)}$. En stands for Error normalised and is defined as,

$$
E_{n}=\frac{L A B-R E F}{\sqrt{U_{L A B}^{2}}+U_{R E F}^{2}}
$$

where:

$L A B$ is the participating laboratory's result REF is the Reference Laboratory's result $U_{L A B}$ is the participating laboraory's reported uncertainty

$U_{R E F}$ is the Reference Laboratoru's reported uncertainty.

For a result to be acceptable the $E_{n}$ ratio should be between -1 and +1 .

In calibration interlaboratory comparisons the $E_{n}$ numbers only indicate whether laboratories are within their particular uncertainty of 
measurement of the Reference value (assigned value) taking into account the uncertainties of measurement. The $E_{n}$ number does not indicate which laboratories is closest to the Reference Value. Consequently, high level calibration laboratories may have similar $E_{n}$ numbers to the laboratories working to a much lower level of uncertainty.

It should be noted that the Reference value itself has an uncertainty of measurement. Consequently, the $\left|E_{n}\right|<1$ limit really only represents the cut-off below which it is likely that the result is acceptable and above which it is unlikely that the result is acceptable. In a series of similar measurement we could also accept a normal distribution of $E_{n}$ ratios. So when considering the significance of any result with $\left|E_{n}\right|$ marginally greater than 1 , all results are evaluated to see if there is a systematic bias e.g. consistantly positive or consistantly negative values of $E_{n}$ may indicate a problem.

\subsection{Observation Method}

In December 2003, Puslit KIM-LIPI, Indonesia and SPRING, Singapore made an arrangement to conduct a bilateral key comparison on dc voltage. The main decisions regarding the comparison were that: Puslit KIM-LIPI would be the pilot laboratory. The comparison voltage would be at $10 \mathrm{~V}$. A Fluke $732 \mathrm{~B}$ serial no, 8440015 owned by Puslit KIM-LIPI would be used as a dc voltage traveling standard. The comparison would proceed in the sequence (Puslit KIM-LIPI)-(SPRING)-(Puslit KIM-LIPI)

Puslit KIM-LIPI made an arrangement for the traveling standard to be hand-carried between Puslit KIM-LIPI and SPRING. After the measurement is completed, each laboratory submitted its data to the APMP TCEM Chairman for collation. The TCEM Chairman wound sent collated data back to both laboratories for preparation of the comparison report.

Schedule of the Comparison is arranged by placing the artifact on both laboratories for measurement in a certain time interval. The artifact was located for measurement in Puslit KIM-LIPI from $12-01-2004$ up to $11-02-$ 2004 and from 25 - 03 - 2004. In turn on the middle of those interval started from $12-02-$ 2004 up to 24 - 03 - 2004, the artifact was placed in SPRING laboratory for measurement.

The laboratories participants involved in this programm, technically, is motivided to measure the artifact as much as possible or at least more then 10 measurement. Regarding of this measurment method would produce quite a lot of data's from the respectivally observation, those data's of laboratories shall be processed in arithmatic to perform a single data to prepare for further analization. To face this condition, the writer will included an analyzed method called a Least square method ${ }^{1,2)}$.

\section{RESULT AND DISCUSSION}

The dc voltage measurement of the Fluke 732B traveling standard was carried out manually in Puslit KIM-LIPI and under computer control in SPRING. Both laboratories carried out measurements of the Fluke 732B output voltage with its power cord removed from the mains power and running on its internal battery. The Fluke 732B was disconnected from the mains power for at least one hour before the commencement of measurements. The Fluke $732 \mathrm{~B}$ guard terminal was connected to system ground and its chassis terminal while the output terminals were left floating. The ambient environmental of both laboratories should be controlled in good condition. Puslit KIM-LIPI and SPRING has been controlled their Temperature, Relative Humidity and Barometric Pressure in $(23 \pm 1)^{0} \mathrm{C} ;(65 \pm 5) \%$ rh ; typical $1024 \mathrm{hPa}$ and $(23 \pm 1)^{0} \mathrm{C} ;(5 \overline{5} \pm 5) \%$ rh ; typical $1013 \mathrm{hPa}$ respectivally.

Although the equipment used at Puslit KIMLIPI and SPRING for maintaining the standard of dc voltage standard is technically prepared in difference system but in unit quantitatively is in the same principle. Puslit KIM-LIPI provided a group of standard cell containing of 3 individual cells that are made in FLUKE with the uncertainty of measurement up to $12 \mu \mathrm{V}$. The measurement system is supported by a nanovoltmeter and a low thermal scanner with it contribution in measurement capability up to $0.025 \mu \mathrm{V}$ and $0.04 \mu \mathrm{V}$ respectivally. This dc voltage unit is currently traceabled to the NMIAAustralia.

Technically SPRING could provide their standard value of 10 volt dc more accurate up to $100 \times$ higher or better than standard cell. The measurement system is build-up based on a Josephson Junction Array. The system is supported by several stable equipments such as a Josephson Array system to generate voltage up to $10 \mathrm{~V}$, Frequency reference, Scanner, Frequency counter, Digital volt meter, Oscilloscope. In these inter laboratory comparison the Josephson Jucntion system was 
capable to measured the artifact with uncertainty of measurement up to $0.2 \mu \mathrm{V}$.

Figure 1 shows the voltage at $10 \mathrm{~V}$ level for the complete sequence Puslit KIMLIPI/SPRING/ Puslit KIM-LIPI. The measurement data from both laboratories is shown in Appendices A and B. All values in Figure 1 are directly from the measurement data without correction to the standard values of ambient. Each point shown on the graph represents the average value of the day.
The estimated measurement uncertainties assigned by each laboratory to its measurements are as follows (see figure 2 and 3). Each of the points in Figure 1 has an associated standard uncertainty whose value is stated as combined standard uncertainty in the tables below.

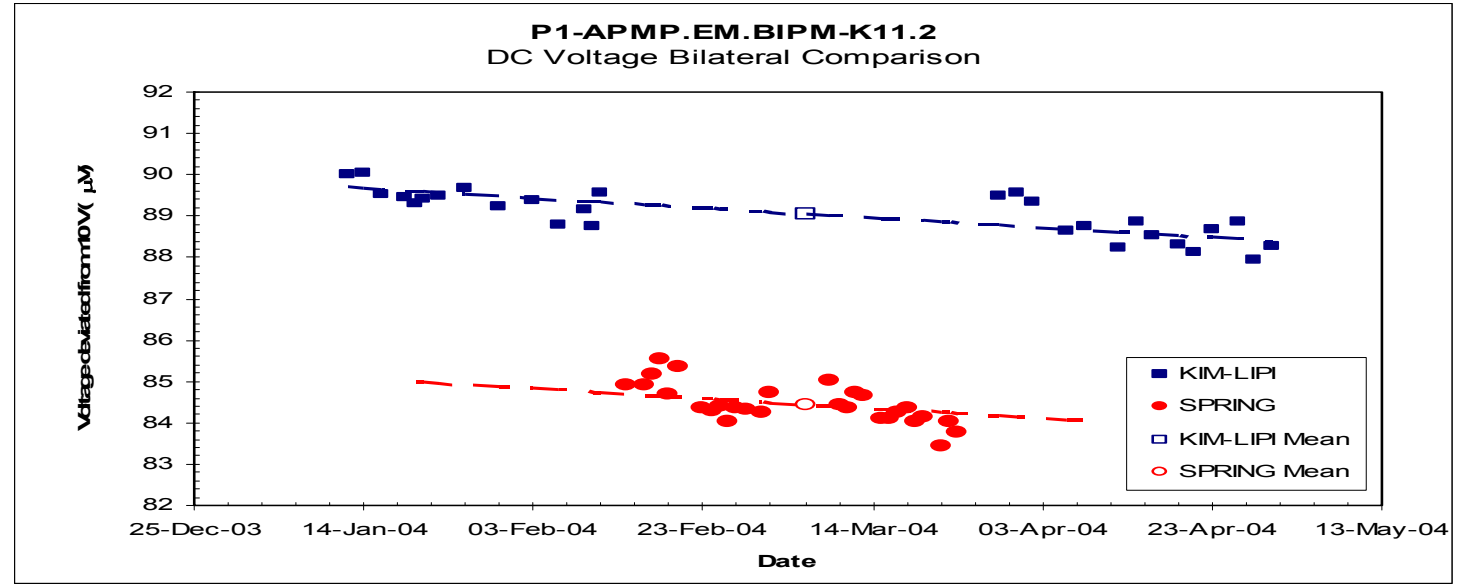

Figure 1 Measurement Result

\section{At Puslit KIM-LIPI}

\begin{tabular}{|l|l|l|}
\hline Components of uncertainty & Type & Standard uncertainty $(\mu \mathrm{V} / \mathrm{V})$ \\
\hline Reference standard & B & 1.2 \\
Drift & B & 0.15 \\
Scanner emf & B & 0.01 \\
Nano-voltmeter & B & 0.003 \\
Cable leakage & B & 0.001 \\
Repeatability & A & 0.02 \\
\hline Combined Standard uncertainty & & 1.212 \\
\hline
\end{tabular}




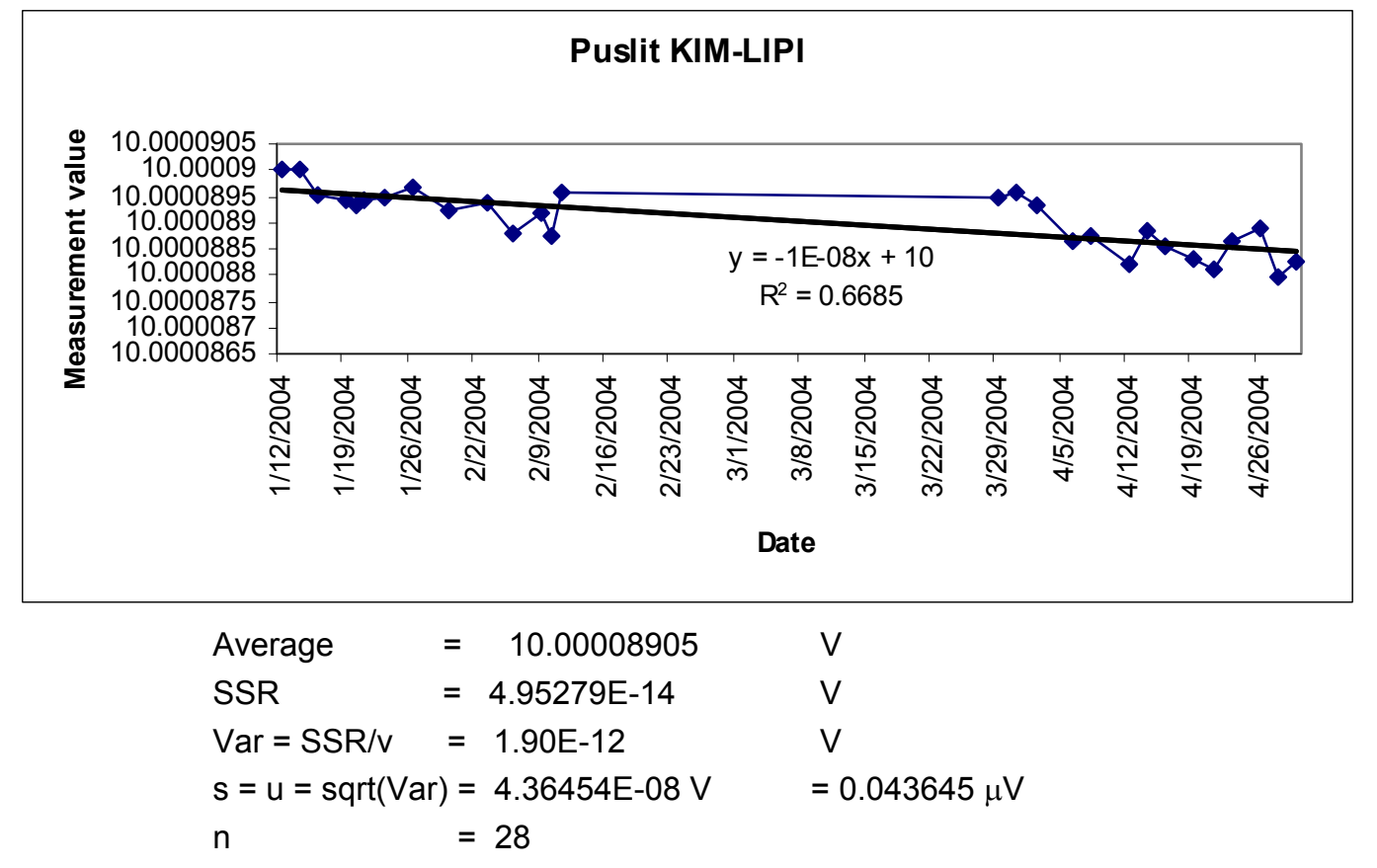

Figure 2 Data Analysis Using Curve Fitting for PUSLIT KIM-LIPI

\section{At SPRING}

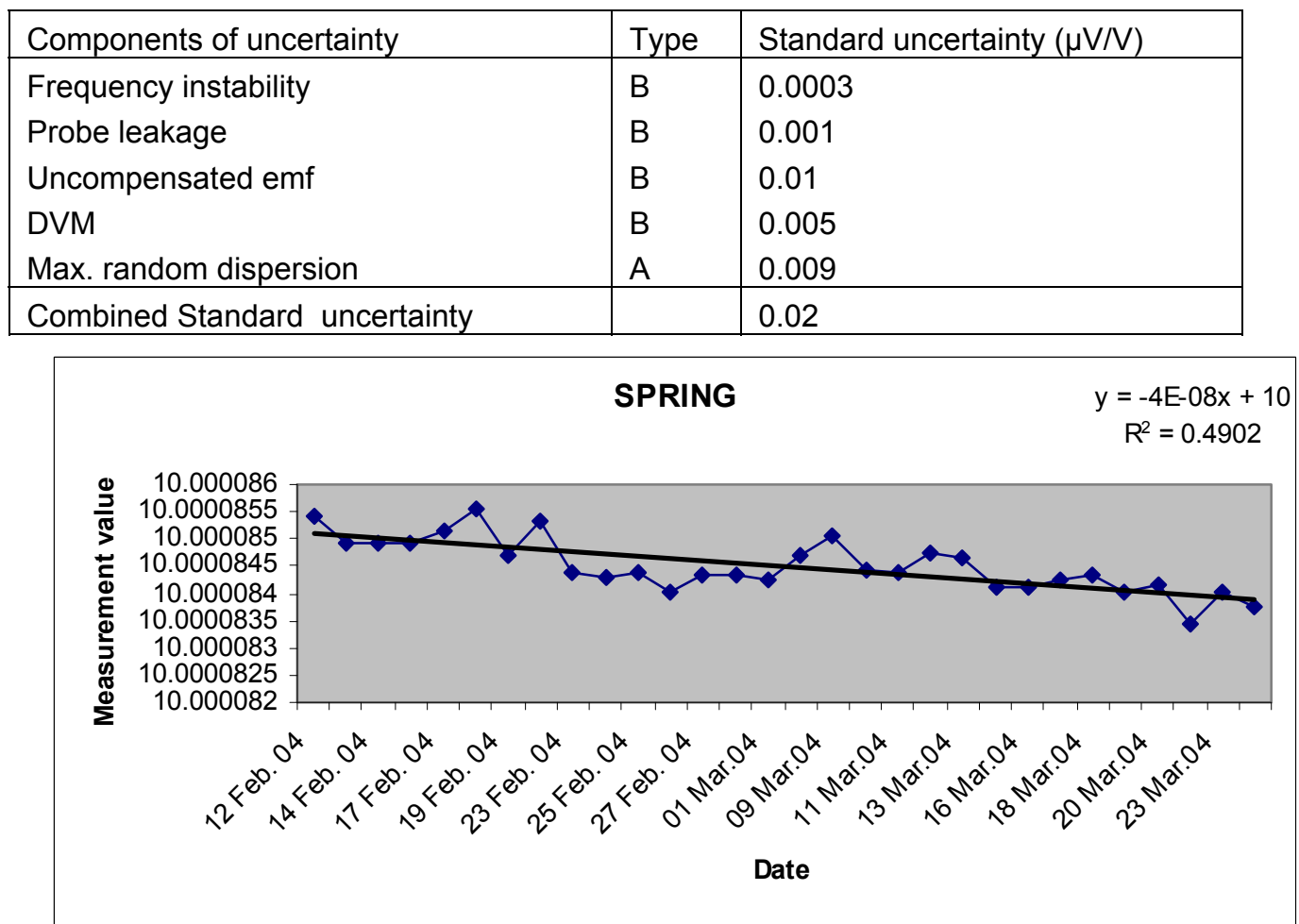




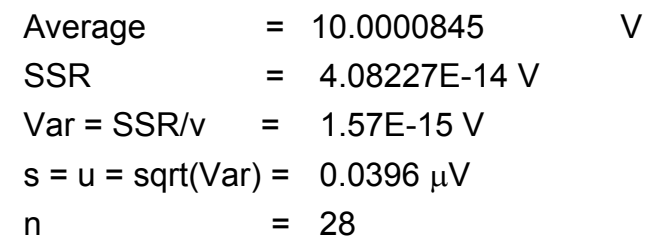

Figure 3 Data Analysis Using Curve Fitting for SPRING

\subsection{Evaluation of the Result}

Since the environmental conditions of both laboratories are comparable and the traveling standard was hand-carried with battery powered between Puslit KIM-LIPI and SPRING to minimise the transportation instability, correction to the standard values of ambient was not applied to the measurement data as the variations are insignificant when compared to the estimated measurement uncertainty. The results were analysed by performing a fit to a first-order drift curve with a constant laboratory-dependent offset as shown by the dash lines in Figure 1.

At the mean date $i=(6$ March 2004), the values deviated from $10.00000 \mathrm{~V}$ for measurement results at Puslit KIM-LIPI and SPRING are $V_{i}^{\text {Puslit KIM- }}$ ${ }^{\mathrm{LIPI}}=89.05241 \mu \mathrm{V}$

$V_{i}^{\text {SPEING }}=84.44293 \mu \mathrm{V}$ respectively. The offset $\Delta$ is $4.60948 \mu \mathrm{V}$.

The difference of measured mean result at Puslit KIM-LIPI from the measured mean result at SPRING is hence:

$V^{\text {Puslit KIM_LIPI }}-V^{\text {SPRING }}=4.60948 \mu \mathrm{V}$ with $a$ standard uncertainty $0.24 \mu \mathrm{V} / \mathrm{V}$.

\subsection{Degree of equivalence of Puslit KIM-LIPI to SPRING}

The degree of equivalence $D^{1}$ between Puslit KIMLIPI and SPRING is:

$D\left(V^{\text {Puslit KIM_LIPI }}-V^{\text {SPRING }}\right)=4.61 \mu \mathrm{V}$ with an expanded uncertainty $0.48 \mu \mathrm{V} / \mathrm{V}$

The expended uncertainty was calculated from the standard uncertainty using a coverage factor $k=2$.

\subsection{Link of Puslit KIM-LIPI result to BIPM}

SPRING participated in a bilateral comparison with BIPM on 27 August 1998 as part of the ongoing BIPM key comparison in dc voltage at $10 \mathrm{~V}$ level (BIPM.EM-K11b) and the following result was obtained:

$V^{\text {SPRING }}-V^{\text {BIPM }}=0.16 \mu \mathrm{V}$ with a standard uncertainty $0.011 \mu \mathrm{V} / \mathrm{V}$,
The linking of Puslit KIM-LIPI result at $10 \mathrm{~V}$ level is thus:

$V^{\text {Puslit KIM_LIPI }}-V^{\text {BIPM }}=4.77 \mu \mathrm{V}$ with a standard uncertainty $0.25 \mu \mathrm{V} / \mathrm{V}$.

Hence the degree of equivalence of Puslit KIM-LIPI to BIPM is:

$D\left(V^{\text {Puslit KIM_LIPI }}-V^{\text {BIPM }}\right)=4.77 \mu \mathrm{V}$ with an expanded uncertainty $0.50 \mu \mathrm{V} / \mathrm{V}$.

The expended uncertainty was calculated from the standard uncertainty using a coverage factor $k=2$.

Regarding to the measurement result of both laboratories (see figure 4) of Puslit KIM-LIPI and SPRING, the expanded uncertainty ${ }^{4}$ of measurement were calculated as shown as 12.12 $\mu \mathrm{V}$ and $0.17 \mu \mathrm{V}$, respectively (see Appendix $\mathrm{A}$ and B). 


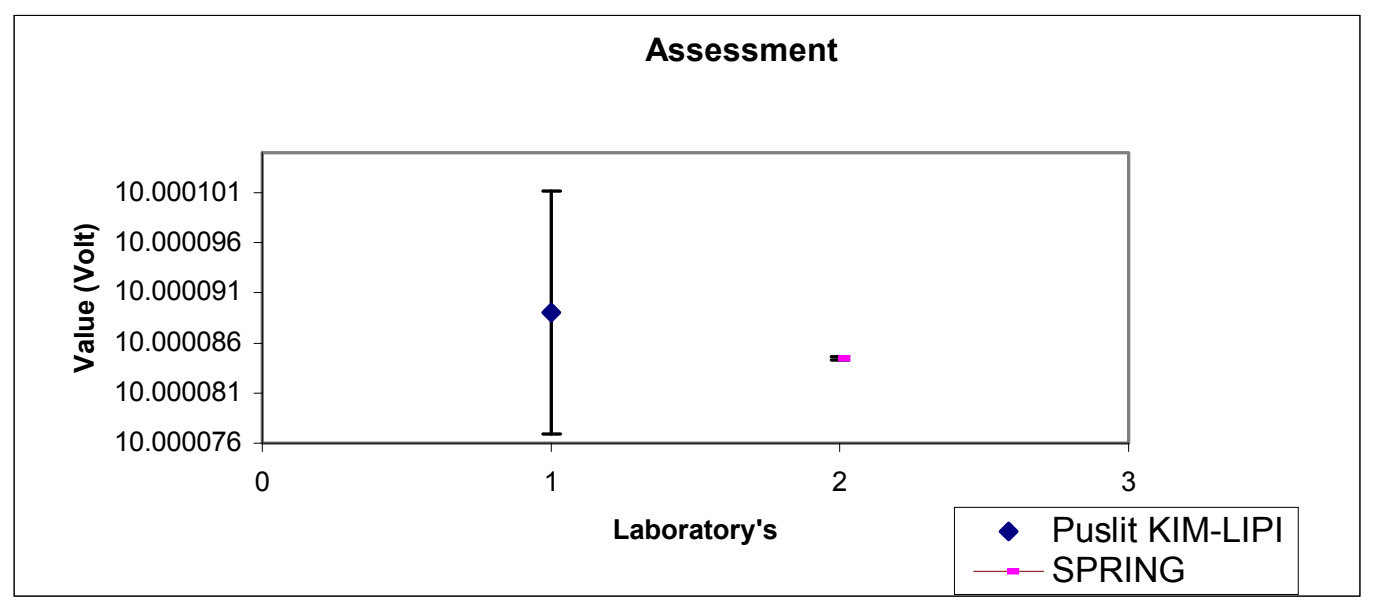

Figure 4 The Diference Value Indication With It Expanded Uncertainty of The Measurement Result

\section{CONCLUSION AND SUGGESSION}

An inter laboratory comparison is one of the most importance processes for a metrology laboratory to get it competency conformity. Puslit KIM-LIPI has been aproved it competerncy through a bilateral comparison with SPRING laboratory for 10 volt dc voltage unit by a valid indication based on the number En up to -0.25 .

It was undirextally described in the above experience that to guaranty in getting a valid indication performance, a laboratory should maintained their traceability of the unit under observed to the higher level standard.

\section{REFERENCES}

1. Carroll, R. J., D. Ruppert, and L. A. Stefanski. 1995. Measurement Error in
Nonlinear Models. London : Chapmann \& Hall.

2. Hardin, J. W. and R. J. Carroll. 2003. Measurement Error, GLMs, and National Conventions. Stata Juournal.

3. "Training Course for Assessors of Calibration Laboratories" , National Association of Testing Authorities, Australia, 1998.

4. "Using The ISO GUM", CSIRO Division of Applied Physics, Melbourne Branch, Clayton, 1994, 1995.

\section{BIODATA}

Hadi Sarjdono, Puslit KIM-LIPI, PUSPIPTEK, Cisauk. Post Graduate Opto elektroteknic and Laser Aplication, Universitas Indonesia, 1991. 